\title{
The Analysisof how to improve the teaching effectiveness of ideological and political lessons
}

\author{
Hongxiang Zhao
}

School of economics and management, Shenyang University of Aeronautics and Astronautics

Keywords: The ideological and political lessons; Teaching effectiveness ; Countermeasures

\begin{abstract}
To make the ideological and political teaching have an important position in the education system in our country, with the development of era, we need to update our teaching content and method constantly. The effectiveness of the ideological and political lessons teaching is an important subject. The article analyzes the problems that exist in the effective teaching of ideological and political lessons and analyzes its reasons and raises methods to solve it to try to provide referential experiences to improve ideological and political lessons.

The implementation of basic education reform in China, the ideological and political lessons have the responsibility to help students to set up the scientific world outlook, the outlook on life and value. It is more important to enhance the effectiveness of ideological and political lesson.

The thought of effective teaching in western is changing all the time. Initially, the westerns' effective teaching ideas pursuit the efficiency of teaching. In the 20th century, western scholars put forward that we should pursue the development of students' personalities as the main characters of teaching effectiveness. Because they realize that the students are the subjects of effective teaching, while they insist whether students have accepted or master the knowledge and teachers' important function on it in their process of exploring. National scholars pointed out that the teaching effectiveness requires teachers to learn to use less manpower and material resources even energy which is close to the students' life and make a perfect teaching plan in the limited teaching time to complete the teaching task and enable students to apply. Domestic scholar Li-min Yao considered effective teaching enabled teachers to use teaching regularity to cause, maintain and promote the students' study enthusiasm successfully, thus to achieve the expected teaching efficiency.
\end{abstract}

\section{The current status of ideological and political lesson's effectiveness.}

The ideological and political lessons progress in the course reform all the time, but there are still some problems, The effectiveness of teaching did not give full play to come out, mainly manifested in the following respects.

The teacher of ideological and political comprehensive quality is not high. On the one hand, the teacher of ideological and political has no sense of himself as an example. Ideological political lessons teachers teach students to be a task, teaching students Marxism. This requires teachers to think of themselves as role models, abide by the code of ethics, really be an example to the students and imperceptibly affect the students. On the other hand, the ideological political lessons teacher's discipline still need to enhance professional quality. The teacher's professional knowledge and teaching ideas and teaching strategies affect the quality of the thought political lesson teaching.

The environment of the ideological political lessons teaching wasn't up to par. Ideological 
political lessons teaching of modern information technology such as multimedia not give full play to the role. Some teachers still are holding a textbook and teaching with a piece of chalk, so it is difficult to arouse the students' interest in learning. There is insufficient in ideological political lessons teaching environment. The ideological political lessons teaching most limited in the classrooms and the classrooms. Students rarely participate in social practice, so it is difficult to the current politics hot spots and life practice and learning theory.

Follow the basic connotation of effective teaching, combine the discipline characteristics and nature of the political lessons, effective teaching is a kind of effective and efficient education, and it is the pursuit for teaching based on the reality and the ideal. The effective teaching in high school political lessons must also comply with the reality of the high school political lessons expect the requirement of effective teaching. There are two basic characteristics in high school political: the first is ideological and political education. Each discipline has the function of intellectual education, but political science not only has the function of intellectual education but also has the function of ideological and political education. This character determines that it has the most important ideological and political educational position in the school education. When it finished the intellectual education, it stressed transformation from cognition to the practice. That is to put the knowledge into practice and to solve the practical problems in our study life. The ideological and political teaching focuses on the cultivation of the ideological and political education can guide the students to set up the scientific outlook, world outlook and values, cultivate students to establish correct national consciousness and citizen consciousness, improve the students' ideological and moral qualities, encourage students to pursuit higher ideological and ethical realm constantly and become the qualified builders and successors of socialism. The second is to keep pace with the times. We must have a thorough understanding of the major principles and policies for the party and the state. Political lessons teaching must also happen with the latest events as the carrier to broaden students' horizons and increase students' knowledge.

\section{Improve the effectiveness of the thought political lesson teaching method}

Improve the teacher's comprehensive quality. The teacher of ideological and political is the dominant force to realize the thought political lesson teaching effectiveness. Teacher's education is the basic strategy to improve the ideological political lessons teaching effectiveness.

First of all, teachers should establish the effective teaching idea. The teacher of ideological and political teaching ideas to guide is to take appropriate actions. The teacher wants to realize teaching and students' learning time is limited. In the limited class teaching time enable students to master knowledge of discipline and flexible use of is very important. So teachers must strive for the best quality to the teaching input, output, and teaching strategies for effective teaching to promote the all-round development of students. At the same time, the teacher of ideological and political has positive emotional attitude. Teachers should love the ideological and political teaching work, put all their effort to cultivate the students' teaching work, teaching for students' development and their own development. At the same time, students are infected by the teacher of ideological and politic this positive emotional attitude, students' learning enthusiasm drive up, imperceptible to promote learning activities effectively. Teachers are the executors and leaders of the whole teaching activities. Teachers need to do a lot of preparations in the process of organizing effective teaching. Teachers can also increase their teaching ability and the accumulation of knowledge in doing this teaching preparation, which can enable them to keep pace with the times of research teaching methods and 
implement teaching strategies. Due to the teachers' professional quality can direct access and direct role in teaching practice and teaching activities, and it has the quality of specialized, and not alternative. Modern teachers should transform experience into practice and attempt to cultivate modern talents for social demand.

Second, the teachers of ideological and political accumulate knowledge. The teacher of ideological and politic must be along with the development of the times need to constantly update their knowledge structure. Ideological and political lessons teaching requirements of the teacher for ideological and politician is mastering Marxist theory of knowledge at the same time to understand the related scientific knowledge, knowledge in psychology and education theory knowledge, etc. The teacher of ideological and political only learns solid professional knowledge, ability in the teaching. Relevant scientific knowledge, knowledge in psychology and education theory knowledge to master will make the teacher of ideological and politic teaching conforms to the law of teaching, scientific use of teaching methods, teaching principles, in the teaching process instance, improve the teaching effect. At the same time, the teacher of ideological and political should pay attention to cultivate their scientific research ability, enhance the professional confidence. Teachers should take an active part in academic seminars, watch the education scientific research related to the lecture, constantly absorb the latest trends, associate with professional experience, achievements, scientific research ability will have greatly improved, to some extent, improve the teachers' comprehensive quality.

Enhance students' learning initiative and enthusiasm. The students' learning attitude and enthusiasm of the ideological and political theory knowledge influence the effectiveness of teaching. Students' learning initiative and enthusiasm of enhancement cannot leave teacher's guidance. Ideological political lessons teachers need to understand the actual situation of the students, to find the solution to the problems, develop to improve the enthusiasm of students learning methods of teaching. The teacher wants to understand the status of the students to learn knowledge to master and students' personality and interests, and the students' growth and progress, and so on. Effective teaching attaches importance to the accumulation of knowledge, but more emphasis on promoting the improvement of students' ability. For example, thinking ability, learn to observe, to cultivate the ability of one instance. Thinking is based on the analysis and sorting and generalization and abstraction and comparison and systematic and so on a series of process. Thinking ability is the core of learning ability, is the key to analyze and solve problems and will promote students observation ability for finding and solving problems, improve creative ability, the embodiment of the students' subjectivity. To cultivate the ability of one instance will help students in learning new knowledge to improve the knowledge also ability. Trains the student to better apply the learned knowledge skills in different situations, thus better learning new knowledge and solve new problems.

First of all, the teacher of ideological and political according to students' mastery of knowledge, combine with the development of political and economic and cultural conditions, guide students to actively explore and analyze the social phenomenon, and solve the problems in life. Contact with students in the actual teaching, the students' initiative into full play and more thorough understanding of the subject knowledge. Students in the learning experience of ideological and political theory is closely related to life, to enhance the learning interest and learning initiative participation will, and enthusiasm to participate in social practice will be high, any ideological political lessons teaching effectiveness can be achieved. The accumulation of knowledge is the basis for the development of students' learning objectives, knowledge education is the common basis of education, is a central part of the modern education. In classes, in order to realize effective teaching content must first 
understand the student to acceptance, ensure that students in the limited teaching time can enhance the accumulation of knowledge, for the full development of students to build solid theoretical basis. Therefore, the political class in high school change blindly rote, but based on the scientific method. Second, the teachers of ideological and political should understand the personality of students. Teachers in the teaching process to create opportunities to give full play to the specialty students. It makes students to obtain a sense of accomplishment and students self motivation and interest in learning. In addition, the teachers in the teaching process should learn carefully found that students' progress and timely to encourage and reward, causes the students to experience the joy of success to study to produce to the desire of learning and innovation. These stimulate students' interest in active learning, and improve the effectiveness of classroom teaching. Effective teaching emphasizes on students' personal in the cultivation of emotions and attitudes, and values. It attaches great importance to the student to the practice experience, full experience in the practice of personal emotions and attitudes and values of things. And then teachers then modify and education. In this way can the teaching of real left in students' psychological emotional experience, feel the fusion of social experience and self experience, emotion and reason of shock bump, only in this way in order to be truly effective teaching.

Build a favorable teaching environment for ideological and political lessons. The effectiveness of ideological and political teaching depends on a favorable teaching environment. Students achieve the best teaching effect during pedagogical only in a favorable teaching environment. Teachers must use modern information technology instead of traditional teaching environment which can depress students' creativity. At the same time, teachers should extend the teaching environment of the lessons and make full use of outside resources to achieve effective teaching.

First of all, the teacher of ideological and political should be in the classroom instruction to give full play to the role of the multimedia and so on. Ideological political lessons teachers should create a lively atmosphere to encourage students to explore. Effective teaching is not only depends on how the teachers teach and how students to do, but also depends on the classroom atmosphere. Create a different classroom atmosphere can make a difference in teaching effect and learning efficiency. So should actively create a good classroom atmosphere is the important condition to realize effective teaching. Classroom atmosphere happens on which students' classroom learning psychological background, by influencing the class activities of middle school students learning motivation and learning behavior and emotional experience and effect evaluation and so on, which restricts the students' classroom learning efficiency. Good classroom atmosphere build needs the teacher's careful organization and take the initiative to create.

Secondly, the teacher of ideological and political should extend the teaching environment of the ideological and political lessons and make full use of outside resources to achieve effective teaching. The ideological and political lessons should break the limitation of teaching environment and let students into the society experience their lives under a particular atmosphere, which can make them combine living practice with learning theory and improve their ability of raise, analyze and solve the problems. The teacher of ideological and political can lead the students to a variety of recruitment fair to experience the condition and flow of recruitment and to help students to set up correct employment attitude. Teachers can lead students to visit kinds of museums and salons which can make students experience the long history and extensive profound of Chinese culture personally, understand the meaning of that 'the more national, the more the world', enhance a sense of national pride and improve the capability of independent innovation. Therefore, create a favorable teaching 
environment will expand students' learning space, promote students' physical and mental to develop better and achieve the effective teaching of ideological and political lessons.

In a word, the ideological political lessons teaching effectiveness is the optimal target of the curriculum reform to achieve. The ideological political lesson study is on the implementation of effective teaching strategy review and reflection on the inefficient political lesson teaching. This is helpful for teachers to change teaching idea and change the teaching mode and innovative teaching strategies, to promote the study of the thought political lesson teaching effectively, promote the ideological and political teachers' professional development. To meet the requirements of basic education reform and development, it is imperative to strengthen the thought political lesson teaching effectiveness.

\section{References}

[1] Tao Xingzhi. Democracy and education. [M].Shanghai: East China Normal University press, 1981

[2] Shen Zhuanghai. The validation study of ideological and political. [M].Wuhan: Wuhan University press, 2008

[3] Ye Lan, Li Zheng, etc. The Research History of New Basic Education. [M].Beijing: Science and education press, 2011

[4 ]Yang Deguang, Zhang Ruitian. Out of the confuse of education let education return to education. [J].Higher education research, 2010(12)

[5] Fan Wei, Ye Bo. The review of 'effective teaching' since 1990s. [J].The journal of Chongqing University (social science edition), 2010(4) 